\title{
A enfermagem como integrante da residência em saúde da família: relato de experiência
}

\author{
Carla Ferreira Regina Baracho, Sylvia Bezerra de Castro, Susane Silva do Nascimento
}

\section{Resumo}

Estudo oriundo da atuação de enfermeiras residentes em saúde da família no município do Rio de Janeiro. Descrever a vivência como residentes da primeira turma do programa de residência do município do Rio de Janeiro. A Estratégia de Saúde da Família surgiu para proceder à organização da prática assistencial em novas bases e critérios, em substituição ao modelo tradicional de assistência médico-curativista. A Residência em enfermagem, sendo forma de treinamento em serviço, consolidou-se como espaço importante de qualificação profissional, possibilitando obtenção do título de especialista. Trata-se de um relato de experiência, do tipo descritivo, de abordagem qualiquantitativa, das ações desempenhadas por 3 enfermeiras inseridas no Programa de Residência em Enfermagem em Saúde da Família, formado pela parceria entre a Secretária de Saúde do Município do Rio de Janeiro e a Universidade do Grande Rio (Unigranrio), no período de março de 2015 a julho de 2016. O programa dura 24 meses, com carga horária de 60 horas semanais, totalizando 5.760 horas, destas $80 \%$ prática e teórico-prático e $20 \%$ teórico. A carga teórica, é composta por aulas divididas em blocos (Trabalho em equipe e visita domiciliar; Atenção centrada na saúde da criança e adolescente; Atenção centrada na saúde do adulto e idoso), proporcionando o suporte teórico-científico, para uma assistência mais qualificada. Ao final, cada residente deve apresentar um trabalho de conclusão de curso, nos moldes de um projeto de intervenção, de acordo com demandas identificadas no seu campo de prática. O campo prático possui 1 preceptor para supervisionar 2 residentes, que assumem uma equipe de saúde da família, desenvolvendo atividades juntamente aos demais profissionais, a população do território adscrito. São realizadas visitas domiciliares, grupos de educação em saúde, consultas de enfermagem, interconsultas com o Núcleo de Apoio a Saúde da Família (NASF), supervisão dos agentes comunitários de saúde, reunião de equipe, campanhas de vacinação, curativos e discussões teóricopráticas, entre preceptores, residentes e outros profissionais das unidades. As atividades desenvolvidas mudam de acordo com o ano de residência no qual se está inserido. No primeiro ano, é desenvolvido prioritariamente atividades assistenciais, com maior carga horária designada aos turnos de consulta de enfermagem, a fim de correlacionar com a prática assistencial ao conhecimento técnico- cientifico, conhecer a população adscrita, capacitar para atividades exercidas no segundo ano. Já no segundo ano, é prioritário o desenvolvimento de atividades de coordenação da equipe de saúde e do cuidado. São realizados estágios externos, que possibilitam capacitar diante de situações de maior complexidade, no molde de plantão, de 12 horas. Dentre os campos, estão Maternidade, Unidade de Pronto Atendimento, Consultório na Rua, Abordagem a vítimas de violência sexual e doméstica - Sala Lilás. Também é realizado o estágio optativo, com duração de 1 mês, que ocorre em unidade de saúde de escolha do residente, a fim de aprimorar a capacidade técnica. A residência modifica o perfil profissional e qualifica a assistência, pois permite conhecer ferramentas disponíveis e tomar decisões mediante embasamento científico, crítico e reflexivo.

Descritores: Residência; Enfermagem; Saúde da família. 